\title{
Comparison of Choroidal Thickness Between Smokers with Non-Smokers Using Optical Coherence Tomography
}

\author{
Vanda Virgayanti ${ }^{\mathrm{a}}$, Delfi ${ }^{\mathrm{b}}$, M. Faisal ${ }^{\mathrm{c}}$

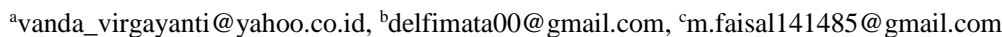 \\ ${ }^{a}$ Ophthalmologist, Ophthalmology Departement, Universitas Sumatera Utara, Indonesia \\ ${ }^{b}$ Ophthalmologist, Ophthalmology Departement, Universitas Sumatera Utara, Indonesia \\ ${ }^{c}$ Ophthalmology Resident, Ophthalmology Departement, Universitas Sumatera Utara, Indonesia
}

\begin{abstract}
Background. Smoking is one of the leading causes of death worldwide. smoking has played a role in the cause of death of approximately 6 million people per year (Muezzinler et al., 2015). While some diseases that cause morbidity and mortality from smoking include myocard infarct, cerebrovascular damage, lung cancer and chronic obstructive pulmonary disease. Smoking is also one of the factors that affects damage to visual disorders, such as cataracts, or macular degeneration (McNabula and Gill, 2009; Mojon et al., 2008). Smoking can result in changes in retinal and choroidal vascular and endothelial reactivity and high risk of affecting the onocyal neovascular (SanGiovanni et al., 2009; Chovdar and Chakravarthy, 2003; Chakravarthy et al., 2007).
\end{abstract}

Method. The study has been done on 78 subjects who met the inclusion criteria were found smokers and 37 people (74 eyes) while non-smokers numbered 41 people (82 eyes) who attended ophthalmologist's outpatient clinic in University of Sumatera Utara (USU) Hospital from July 2019. Visual Acuity and Choroidal Thickness were measured and compared.

Result: From 78 research subjects, most subjects were aged $\leqslant 30$ years, male, filter smokers with smoking frequency $\leqslant 1$ packs and duration $\leqslant 10$ years. This study used the t-test independent test analysis and found that CT depletion was statistically significant in the group of smokers with a $p$ value $=0.002$. In more detail, a group of non-filter smokers is known to have significant CT depletion with $p=0.001$ in the right eye and $p=0.002$ left eye compared to filter smokers. The duration of smoking is also known to cause CT depletion especially in smokers> 10 years where $\mathrm{p}=0.001$ in the right and left eye is the same. In the group of smokers with total cigarette consumption> 1 pack / day, there was a significant CT depletion with $p=0.001$ in the right eye and $p=0.004$ in the left eye.

Conclusion. There was a significant depletion in the choroidal thickness of the smokers group.

Published by IJRP.ORG. Selection and/or peer-review under responsibility of International Journal of Research Publications (IJRP.ORG) 


\section{Introduction}

Smoking is a serious problem in the public health of the world. The WHO estimates about 1.1 billion people smoke. Indonesia is a country with a high rate of cigarette use. Health ministry data shows an increase in the prevalence of smokers from 27\% in 1995, increasing to $36.3 \%$ in 2013 (Chakraborty et al., 2007). According to the data of Global Youth Tobacco Survey (GYTS) Indonesia in 2014, the data of Indonesian smokers over 15 years is $30 \%$, as age increases, the percentage of smokers continues to increase (WHO, 20140. According to the WHO, the definition of smoker is those who smoke daily for a period of at least 6 months during their lifetime still smoking (Depkes, 2004). According to Davitson et al (1998) the definition of smoker is a person who has smoked 1 or more sticks every day for at least a year, if for 1 month leave cigarettes (not smoking) is referred to as a history of smokers, If for 5 years quit smoking then referred to as former smokers (Davidson and Taylor, 1998; Leffondre and Abrahamovicz, 2002). Passive smokers are cigarette smoke inhaled by someone who does not smoke (Pasive Smoker). Active smokers are smokers who inhale cigarette smoke derived from smokers' smoke or main smoke in smoked cigarettes (Davidson and Taylor, 1998). Resch et al study in 2005, reported that retinal and choroidal blood flow increased during carbon monoxide inhalation (CO), which is a major component of cigarette smoke (Mojon et al., 2008; WHO, 2014). The effects of cigarettes not only cause damage to the choroidal, but also can cause damage to the macula to the entire retina.12 Smoking can cause vascular changes in the retina and coronary as well as endothelial reactivity and is at high risk of affecting the choroidal neovascular (SanGiovvani et al., 2007; Chovdar and Chakravarthy, 2003; Chakravarthy et al., 2007). Some previous studies such as Sigler et al in 2014, stated that in addition to the incidence of AMD, smoking is also associated with choroidal depletion, as well as a 2013 Symaz et al study which stated that choroidal thickness tends to decrease by 1-3 hours after a person smokes (Syzmaz et al., 2013). The most recent research assessing normal choroid values, such as the Enzetari et al 2018 study stated that the average normal choroidal thickness at the sub fovea is $366 \mu \mathrm{m}$, at $1500 \mu \mathrm{m}$ and $3000 \mu \mathrm{m}$ towards the nasal passages is $293 \mu \mathrm{m}$ and $195 \mu \mathrm{m}$, while the temporal is at $1500 \mu \mathrm{m}$ and $3000 \mu \mathrm{m}$ is $314 \mu \mathrm{m}$ and $268 \mu \mathrm{m}$ (Ikuno et al., 2010). Therefore, in this study, researchers wanted to find out the Comparison Of Choroidal Thickness Between Smokers With Non-Smokers Using Optical Coherence Tomography.

\section{Methods}

This research is a prospective analytical cross-sectional method by taking the data from patients at The University of Sumatera Utara Hospital in 2019. The study population was taken from patients who visited University of Sumatera Utara Hospital who met the inclusion criteria (patients treated in the University of Sumatera Utara Hospital willing to participate in the study) and exclusion criteria (smoking patients with other systemic diseases, patients with refractive errors $>3 \mathrm{D}$ and astigmatism $>1 \mathrm{D}$, smoking and non smoking patients with posterior segment disorders and patients who were not willing to participate in the study). The sample size was determined by consecutive sampling method, with a minimum number for each group of 35 people.

\section{Result}

The research subjects were patients who visited the USU Hospital eye clinic in July - September 2019. The total number of research subjects was 78 people (156 eyes), of which 41 people were smokers and 37 people (74 eyes) while non-smokers were 41 people (82 eyes). 
Table 1. Patient Demographic

\begin{tabular}{|c|c|c|}
\hline Patient Demographic & & \\
\hline \multicolumn{3}{|l|}{ Age } \\
\hline$\leq 30$ years old & 42 & $53,8 \%$ \\
\hline$>30$ years old & 36 & $46,2 \%$ \\
\hline \multicolumn{3}{|l|}{ Gender } \\
\hline Male & 36 & $46,2 \%$ \\
\hline Female & 42 & $53,8 \%$ \\
\hline \multicolumn{3}{|l|}{ Smoking (Male) } \\
\hline No & 6 & $16,7 \%$ \\
\hline Yes & 30 & $83,3 \%$ \\
\hline \multicolumn{3}{|l|}{ Smoking (Female) } \\
\hline No & 35 & $83,3 \%$ \\
\hline Yes & 7 & $16,7 \%$ \\
\hline \multicolumn{3}{|l|}{ Cigarette } \\
\hline Filter & 28 & $75,7 \%$ \\
\hline Non filter & 9 & $24,3 \%$ \\
\hline \multicolumn{3}{|l|}{ Cigarette/ day } \\
\hline$\leq 1$ pack & 29 & $78,3 \%$ \\
\hline$>1$ pack & 8 & $21,7 \%$ \\
\hline \multicolumn{3}{|l|}{ Duration } \\
\hline$\leq 10$ years & 26 & $70,2 \%$ \\
\hline$>10$ years & 11 & $29,8 \%$ \\
\hline
\end{tabular}

In Table 1, it shows the distribution of the characteristics of research subjects, where the largest number of subjects aged $\leqslant 30$ years are 42 people $(53.8 \%)$. For the male gender as many as 36 people $(46.2 \%)$ with 30 people who smoke $(83.3 \%)$, while the female subject is 42 people $(53.8 \%)$ with 7 people who smoke.

Subjects who smoke filters are 28 people $(75.7 \%)$ and non-filtered are 9 people $(24.3 \%)$. Subjects who smoked $\leqslant 1$ pack were 29 people $(78.3 \%)$ and $>1$ pack were 8 people $(21.7 \%)$. Subjects with smoking duration $\leqslant 10$ years were 26 people $(70.2 \%)$ and $>10$ years were 11 people $(29.8 \%)$.

Table 2. Comparison of Choroidal Thickness (CT) of Smokers and Non-Smokers

\begin{tabular}{|c|c|c|c|}
\hline \multicolumn{3}{|c|}{ Smoking habit } & \multirow{4}{*}{$p$} \\
\hline \multirow[t]{3}{*}{ Chorodal Thickness (CT) } & Smoker & Non smoker & \\
\hline & $(n=37)$ & $(\mathrm{n}=41)$ & \\
\hline & $x \pm S D$ & $x \pm S D$ & \\
\hline Sub Fovea OD & $273.14 \pm 11.91$ & $282.39 \pm 13.43$ & $0.002 *$ \\
\hline Sub Fovea OS & $274.16 \pm 12.52$ & $280.10 \pm 11.93$ & $0.035 *$ \\
\hline
\end{tabular}


Ps :

*Significant

In Table 2, shows the CT comparison of smokers and non-smokers in the right eye. It can be seen that results of the independent t-test show $p=0.002$ where $p<0.050$. This indicated a statistically significant difference in CT of the right eye. Likewise CT smokers and non-smokers in the left eye. It can be seen that the independent t-test results show $\mathrm{p}=0.035$ where $\mathrm{p}<0.050$. This indicated a statistically significant difference in CT of the left eye.

Table 3. Comparison of Choroidal Thickness (CT) of smokers inhaling filter cigarette with non-filter

\begin{tabular}{|c|c|c|c|}
\hline \multirow{4}{*}{ Choroidal Thickness (CT) } & \multicolumn{2}{|c|}{ Cigarette } & \multirow{2}{*}{$p}$. \\
\hline & Filter & Non Filter & \\
\hline & $(n=28)$ & $(n=9)$ & \\
\hline & $x \pm S D$ & $x \pm S D$ & \\
\hline Sub Fovea OD & $277.36 \pm 9.65$ & $260.00 \pm 8.23$ & $0.001 *$ \\
\hline Sub Fovea OS & $277.64 \pm 11.44$ & $263.33 \pm 9.42$ & $0.002 *$ \\
\hline
\end{tabular}

Note :

T-Independen Test

*.Significant

In Table 3, shows the CT comparison of filter smokers and non-filter smokers in the right eye. It can be seen that the independent t-test results show $\mathrm{p}=0.001$ where $\mathrm{p}<0.050$. This indicated a statistically significant difference in CT of the right eye. Likewise, the CT of filtered and non-filter smokers in the left eye. It can be seen that results of the independent t-test show $p=0.002$ where $p<0.050$. This indicated a statistically significant difference in CT of the left eye.

Table 4. Comparison of Choroidal Thickness (CT) of Smokers $\leqslant 10$ Years With> 10 Years

\begin{tabular}{|c|c|c|c|}
\hline \multirow{4}{*}{ Choroidal Thickness (CT) } & \multicolumn{2}{|c|}{ Duration } & \multirow{4}{*}{$p$. } \\
\hline & $\leq 10$ years & $>10$ years & \\
\hline & $(n=26)$ & $(\mathrm{n}=11)$ & \\
\hline & $x \pm S D$ & $x \pm S D$ & \\
\hline Sub Fovea OD & $278.77 \pm 9.32$ & $261.00 \pm 7.95$ & $0.001 *$ \\
\hline Sub Fovea OS & $278.69 \pm 11.07$ & $263.45 \pm 8.84$ & $0.001 *$ \\
\hline
\end{tabular}

In Table 4, shows the CT comparison of smokers $\leqslant 10$ years and $>10$ years in the right eye. It can be seen that the independent t-test results show $\mathrm{p}=0.001$ where $\mathrm{p}<0.050$. This indicated a statistically significant difference in CT of the right eye. Likewise CT of smokers $\leqslant 10$ years and $>10$ years in the left eye. It can be seen that results of the independent t-test show $p=0.001$ where $p<0.050$. This indicated a 
statistically significant difference in CT of the left eye.

Table 5. Comparison of Choroidal Thickness (CT) of Smokers $\leqslant 1$ Packs / day With> 1 pack / day

\begin{tabular}{lccc}
\hline Choroidal Thickness $(\boldsymbol{C T})$ & $\leq 1$ pack & $>1$ pack & \multirow{2}{*}{$\boldsymbol{p}$} \\
\cline { 2 - 3 } & $(\mathrm{n}=29)$ & $(\mathrm{n}=8)$ & \\
& $x \pm S D$ & $x \pm S D$ & \\
\hline Sub Fovea OD & $276.55 \pm 10.57$ & $260.75 \pm 7.68$ & \\
Sub Fovea OS & $277.17 \pm 11.64$ & $263.25 \pm 9.48$ & \\
\hline
\end{tabular}

Note :

T-Independen Test

*.Significant

In Table 5 , shows the CT ratio of smokers $\leq 1$ pack / day and $>1$ pack / day in the right eye. It can be seen that the results of the independent t-test show $\mathrm{p}=0.001$ where $\mathrm{p}<0.050$. This indicated a statistically significant difference in CT of the right eye. Likewise, CT smokers $\leq 1$ pack / day and $>1$ pack / day in the left eye. It can be seen that the results of the independent t-test show $p=0.004$ where $p<0.050$. This indicated a statistically significant difference in CT of the right eye.

\section{Discussion}

The table 1 found that the $\leqslant 30$-year-old smokers were 42 , male. This is in line with riskesdas in 2013, which stated that the number of smokers in men is 16x more than women, with the age of first smoking at the age of 15-19 years old (Depkes, 2013).

Table 2, describes the comparison of CT conditions between smokers and non-smokers. In this study, CT was obtained in the right eye sub fovea $\mathrm{p}=0.002$ and in the left eye $\mathrm{p}=0.035$ which means there are significant differences in the CT of the right eye and left eye. This is in line with Sigler J et al in 2014 study which stated smoking is closely related to choroidal depletion. This is closely related to AMD disease, which according to Klein $\mathrm{R}$ et al in 2010 a smoker has a great risk of suffering from AMD (Klein et al., 2001).

There is research that is not in line with Dervisogullari et al's 2014 study which stated smoking was not associated with CT depletion (Dervisogullan et al., 2014).

Table 3 describes the comparison of the CT state of smokers using filters with non-filters. In this study, CT was obtained in the right eye sub fovea $\mathrm{p}=0.001$ and in the left eye $\mathrm{p}=0.002$ which means there are significant differences in the CT of the right eye and left eye. According to Tawbariah et al in 2014, smoking using filters can reduce chemical compounds ( Tar) that are carcinogenic to the body, where Tar consists of Dioxin compounds (Bustan, 2000; Tawbariah, 2014).

Table 4 describes the ratio of the CT state of smokers $\leqslant 10$-years and $>10$ years. In this study obtained the thickness of sub fovea in the right eye $\mathrm{p}=0.001$ and left eye $\mathrm{p}=0.001$. In the group of smokers there appeared to be a thinning of CT in smokers $>10$ years thinner. This is in line with the study of Marlita et al in 2015 which stating that CT depletion occurs in smokers who have smoked for more than 25 years. It is also in line with other studies such as Barteselli G et al in 2012 and Fujiwara T et al in 2009 which stated there is depletion in smokers who actively smoke from young to old age (Barteselli et al., 2012; Fujiwara et al., 2009; Marilita et al., 2015).

Table 5 describes the comparison of the CT state of smokers with the consumption of the number of 
cigarettes/day $\leqslant 1$ pack with $>1$ pack. In this study obtained the thickness of sub fovea in the right eye $\mathrm{p}=0.001$ and left eye $\mathrm{p}=0.004$. In this study, the depletion of CT was found in smokers $>1$ pack/day. In contrast to Xin w et al research in 2018, stated there is no relationship of CT differences, the retinal layer of smokers 8-12 packs/year with no smokers (Xin et al., 2018).

\section{Conclusion}

- There were significant differences in ct of the right eye and left eye between the group of smokers and the non-smoker group where the CT of the smoker was thinner.

- There are significant differences in ct of the right eye and left eye of filter smokers and non-filters where the CT of non-filter smokers is thinner.

- There are significant differences in ct of the right eye and left eye of smokers $\leqslant 10$ years with $>10$ years where ct smokers $>10$ years thinner.

- There are significant differences in ct of the right eye and left eye of smokers $\leqslant 1$ pack/day with $>1$ pack/day where ct smokers $>1$ pack thinner.

\section{References}

Muezzinler U., Mons C., Gellert et al. 2015. Smoking and all-cause mortality in older adults: results from the CHANCES consortium. American Journal of Preventive Medicine; vol.49(5): pp. e53-e63.

McNabola A, Gill LW. 2009. The Control of Environmental Tobacco Smoke: A Policy Review. Int J Environ Res Pub Health; vol.6:741-758.

Mojon-Azzi SM, Sousa-Poza A, Mojon DS. 2008. Impact of low vision on well-being in 10 european countries. Ophthalmologica; Ed.222: 205-212.

SanGiovanni JP, Chew EY, Clemons TE, et al. 2007. The relationship of dietary carotenoid and vitamin A, E, and C intake with agerelated macular degeneration in a case-control study: AREDS Report. Arch Ophthalmol; Vol.22: 125(9); $1225-32$.

Chovdar A, Chakravarthy U. 2003. Age Macular Degeneration. British Medical Journal; UK. Vol.326: pp. 485-88.

ChakravarthyU., AugoodC., BenthamGC., et al. 2007. Cigarette smoking and age-related macular degeneration in the EUREYE Study. Ophthalmology Int J; 114(6): 1157-63.

Chakraborty I, Kunti S, Bandyophadhay M, et al. 2007. Evaluation of Serum Zinc and Plasma SOD Activity in Senile Cataract Patients Under Oxidative Stress. Indian Journal of Clinical Biochemistry. India; Vol.22: pp. 109.

World Health Organization. 2014.Global Youth Tobbaco Survey (GYTS) Indonesia Report. Jakarta; Indonesia.

Depertemen Kesehatan Republik Indonesia. 2004. Konsumsi Rokok dan Prevalensi Merokok. Jakarta; Depkes RI

Davidson A.G., Taylor A.J.N. 1998. Cadmium Fume Inhalation and Emphysema in Lancet. pp. 663-667.

Leffondre K., Abrahamowicz M. 2002. Modelling Smoking History: A Comparison of Different Approach. American Journal of Epidemology. Vol.156(9): pp. 813-23.

Syzmaz S., Kuc C., Ukerdonmez, et al. 2013.The Effect of Smoking on Choroidal Thickness Measured by Optical Coherence Tomography.BritishJournal of Ophthalmology; vol. 97(5): pp. 601-604.

Ikuno Y., Kawaguchi K., Yasuno Y., et al.2010.Choroidal Thickness in Healthy Japanese Subjects. Invest Ophthalmol Vis Sci; Vol. 51(4): pp. 2173-6

Depkes RI. 2013. Riset Kesehatan Dasar. Jakarta; Badan Penelitian dan Pengembangan Kesehatan Kementerian Kesehatan RI.

Klein R., Cruickshanks K.J., Nash S.D., et al. 2001. The Prevalence of Age-Related Macular Degeneration and Associated Risk Factors. Arch Ophthalmol;Vol.128: pp. 750-58.

Dervisogulları M.S, Totan Y., Tenlik A., et al.2014. Effects of Cigarette Smoking on Choroidal and Retinal Thickness And Ocular Pulse Amplitude. Cutaneous and Ocular Toxicology; vol.34(3): pp. 217-221.

Bustan. 2000. Epidemiologi Penyakit Tidak Menular. Jakarta: PT Rineka Cipta

Tawbariah. 2014. Hubungan konsumsi rokok dengan perubahan tekanan darah pada masyarakat di pulau pasaran kelurahan kota karang, kecamatan teluk Betung Timur, Bandar Lampung. Med J of Lampung Univ; Vol. 3(6): pp. 91-98.

Barteselli G., Chhablani J., El-Emam S., et al. 2012. Choroidal Volume Variations with Age, Axial Length, and Sex in Healthy Subjects Three- Dimensional Analysis. Ophthalmology Journal. Vol.119: pp. 25728.

Fujiwara T., Imamura Y., Margolis R., et al. 2009. Enhanced Depth Imaging Optical Coherence Tomography Of The Choroid In Highly Myopic Eyes. Am J Ophthalmol;Vol.148: pp44-50.

Marilita M., Eirini N., Konstantinos L., et al. 2015. Impact of Chronic tobacco smoking on retinal and choroidal Thickness in Greek population. Hindawi Int J; Vol.2016: pp1-7.

Xin W., Sumit K., Jianbing D., et al. 2018. Choroidal Structural Changes in Smokers Measured Using Choroidal Vascularity Index. 
Singapore. ARVO Journal; Vol.60(5): 1316-20. 